\title{
In Search of "Red Ellen” Wilkinson Beyond Frontiers and Beyond the Nation State
}

\author{
MATT PER RY \\ School of History, Classics and Archaeology, Armstrong Building, \\ University of Newcastle, Newcastle $N E_{I}>R U$, United Kingdom \\ E-mail: matt.perry@ncl.ac.uk
}

\begin{abstract}
AвSTRACт: This article reconsiders the life of Ellen Wilkinson (I89I-I947) - British Minister of Education from I945 to 1947 and leader of the Jarrow Crusade of I936 - by exploring the transnational aspect of her politics. It seeks to establish the significance of her transnational orientation and how this can allow us to complement and deepen existing understandings of her. Drawing on the literature on transnational activist networks, it outlines the complexity of transnational networks and her repertoire of transnational political practice. Without serious attention to this global dimension of her politics, our understanding of Wilkinson is attenuated and distorted. Crucially, the heroic construction of "Red Ellen" in both labourist and socialistfeminist narratives has obscured her second radicalization (1932-1936) and the sharpness of her metamorphosis into a mainstream Labour Party figure in 1939-1940.
\end{abstract}

Ellen Wilkinson has been described as “arguably Britain's most important woman politician". Due to her reputation for fiery radicalism, "Red Ellen" has persisted in the collective memory of Britain's i930s. 'This article will explore her internationalism and the transnational aspect of her politics in order to reconsider her political trajectory, and to provide a detailed case study of transnational practice in the era of the two world wars.

Conventional accounts of her career rightly emphasize domestic political achievements and a rootedness in a British left tradition. Her political life began at sixteen when she joined the Independent Labour Party while still at school. After university in 1913, she became an organizer for the suffrage movement, and two years later a national organizer for the Amalgamated Union of Co-operative Employees. Sympathetic to the Russian revolution, she was a founding member of the Communist Party of Great Britain. In 1924, she left the Communist Party and entered the House of Commons as a Labour MP, representing Middlesbrough

I. Kenneth O. Morgan, Labour People (Oxford, I987), p. Iог. 
East (I924-I93I), and later Jarrow (1935-1947). As a leading Labour politician, she served twice (1927-1929 and 1935-1947) on the Labour Party National Executive Committee (NEC). However, she is best remembered for the march in 1936 of her unemployed constituents to London known as the Jarrow Crusade. Despite repeated friction with party managers, her career continued to advance. During World War II she served in Churchill's coalition cabinet as Parliamentary Secretary to the Minister of Home Security, having special responsibility for the politically sensitive issues of air-raid shelters, fire-watching, and civil defence. Finally, in August 1945, she was appointed Minister of Education in Clement Attlee's Labour government but died in office only eighteen months later.

For Betty Vernon, the principal authority on Wilkinson, "Red Ellen" was largely a pragmatist who passed through apprenticeships in the suffrage movement, in the Communist Party (stressing brevity), and in her trade union, before maturing as a campaigning but reformist socialist. ${ }^{2}$ Stressing continuities and gradualism, Vernon's account fits in with labourist and socialist-feminist narratives of her life, of which there have been a number. Alternately, David Reid identified a more subtle trajectory, emphasizing Wilkinson's ideological evolutions from ethical socialism to guild socialism, and thence to communism. For him, Wilkinson's spell in the Communist Party was a formative experience. However, after 1926, she adopted "an amalgam of parliamentary socialism and electoral activity". 3 This article instead proposes a different itinerary. Wilkinson underwent two radicalizations: in 1917-1923 and 1932-1936 - both followed by drifts leading ultimately to a break with her militant past in 1939-1940.

The orthodoxy that Wilkinson's politics were domestically shaped and relatively stable after 1926 will be questioned in two ways. Firstly, a synchronic investigation will explore the significance of her transnational practice and its five principle modes: conference attendance, journalism, acting as a political hostess, missions of investigation, and solidarity. Travel was for her a political practice, and this relied upon overlapping networks: the unions, the peace movement, the women's movement, the Labour and Socialist International (LSI), and the Comintern. ${ }^{4}$ Through journalism, public oratory, and campaigning, her transnational activities were incorporated into her domestic political persona and activity and,

2. Betty Vernon, Ellen Wilkinson, I89I-1947 (London, 1982).

3. T.D.W. Reid, "Ellen Wilkinson: Revolutionary Politics and Ideology, 1917-1926" (thesis without award, Hull University, I984), p. 20.

4. Deborah Stienstra, Women's Movements and International Organizations (Houndmills, 1994), pp. 55-6I; Julie Carlier, "Forgotten Transnational Connections and National Contexts: an 'Entangled History' of the Political Transfers that Shaped Belgian Feminism, I 890-1914", Women's History Review, I9 (2010), pp. 503-522. 
indeed, were constitutive of her politics. Without serious attention to her wider spatial horizons, our understanding of Wilkinson is attenuated and distorted.

Secondly, from a diachronic viewpoint, transnationalism will be deployed to rethink her intellectual itinerary and how she reworked her own sense of internationalism. Biographers have used a transnational perspective to shift their assumptions about their subject. They believe that this also provides a dividend for understandings of transnational networks. Karen Hunt's study of Dora Montefiore demonstrates how biography improves our appreciation of "what transnationalism means in practice". 5 Montefiore and Wilkinson had much in common, being committed to travel, transnational activism, and internationalist ideas. Hunt observed that neither national historiographies nor those of transnational organizations served Montefiore well because she defied simple categorization, moving between different left currents and mixing socialism with feminism in a fluid amalgam. This might equally be said of Wilkinson.

Transnationalism has provided a concept allowing exploration of those features of modernity that cross politically bounded territories. ${ }^{6}$ According to Sidney Tarrow, transnational activists become "rooted cosmopolitans", while travelling "cognitively and physically outside their spatial origins, they continue to be linked to place, to the social networks that inhabit that space, and to the resources, experiences and opportunities that place provides them with". 7 Tarrow's local-cosmopolitan duality can illuminate Wilkinson's entangled network of solidarity, acquaintance, and common endeavour, as well as her intellectual development. On both these counts, her local rootedness combined with cosmopolitanism. Thus, Wilkinson's ideas, while rooted in British left political tradition, were drawn at particular moments into a transnational field of force. For Wilkinson, internationalism prompted transnational activism. However, there is no simple equation between the two. While transnationalism can apply to phenomena such as migrants, commodities, and political or cultural practices, internationalism is a political ideology.

As Perry Anderson has noted, prevailing internationalisms come and go, each with its own corresponding moment of capitalism, working definition, geographical domain, philosophical idiom, and relation to

5. Karen Hunt, “Transnationalism in Practice: The Effect of Dora Montefiore's International Travel on Women's Politics in Britain before World War I", in Pernilla Jonsson, Silke Neunsinger, and Joan Sangster (eds), Crossing Boundaries: Women's Organizing in Europe and the Americas, I880s-1940s (Uppsala, 2007), pp. 73-94.

6. Patricia Clavin, "Defining Transnationalism", Contemporary European History, I4 (2005), pp. $42 \mathrm{I}-439$.

7. Sidney Tarrow, "Rooted Cosmopolitans and Transnational Activists", at http://government.arts. cornell.edu/assets/faculty/docs/tarrow/rooted_cosmopolitans.pdf; last accessed I4 April $20 \mathrm{I} 2$. 
the dominant classes. His historicization provides useful insights. Most pertinently, the assumed incompatibility between internationalism and nationalism is a fallacy; instead the pair have reconfigured in a host of ways. ${ }^{8}$ As regards Anderson's periodization, Wilkinson's life spanned ruptures in internationalism (1917, 1939, and 1945) encouraging examination of these moments. Anderson's macro-analysis and focus on singular prevailing forms of internationalism might be enriched by the kind of microhistory undertaken here. While his definition of internationalism as a political ideology is a useful departure point, three qualifications are useful for this study.

First, while Anderson considered historically dominant modes of socialist internationalism, historians have explored others that have a bearing on this study: feminist, scientific (given Wilkinson's role in UNESCO), labour, and literary internationalism. ${ }^{9}$ Secondly, the emphasis on internationalism as an ideology rooted in forms of enlightenment or religious universalism can obscure its entanglement with a realm of practical action and shared interests. Marcel van der Linden's conceptualization of labour internationalism provides a useful corrective on this score. Not only does this better explain the emergence of the international labour institutions and networks in which Wilkinson participated, this was also how she understood and communicated her internationalism: as shared interests, practical solidarity, common struggles, "normative involvement", and cognitive dialogue. ${ }^{10}$ Thirdly, rather than these longue durée perspectives, Patricia Clavin has confronted internationalism in specific relation to the interwar period as a contest between the liberal and communist (or proletarian) internationalisms which characterized this time. ${ }^{\text {II }}$ These contested internationalisms constituted the bearings for Wilkinson's own internationalism and help to clarify her intellectual trajectory, which passed from communist to liberal internationalism.

\section{THE TRANSNATIONAL ELEMENT OF WILKINSON'S POLITICS, CULTURE, AND HISTORY}

Given the construction of sub-national identities (north-east England and Manchester or Lancashire) and institutional myth-making (the labour movement) regarding her, it is understandable that the existing accounts of "Red Ellen" present a narrative of her life that seriously underestimates

8. Perry Anderson, "Internationalism: A Breviary", New Left Review, I4 (2002), pp. 5-25.

9. Daniel Laqua (ed.), Internationalism Reconfigured: Transnational Ideas and Movements Between the World Wars (London, 2011).

I0. Marcel van der Linden, Workers of the World: Essays Toward a Global Labor History (Boston, MA, 2008), pp. 259-283.

I I. Patricia Clavin, "Conceptualising Internationalism Between the World Wars", in Laqua, Internationalism Reconfigured, pp. 5-6. 
the significance of international affairs upon her intellectual makeup and political itinerary. Nevertheless, there are particular reasons why she should be viewed from a transnational standpoint.

Her ideas prior to her foreign trips or Communist Party membership were internationalist, anticipating her emergent transnational practice. Thus, Wilkinson was part of a new international women's organization founded during World War I: the Women's International League of Peace and Freedom (WILPF). Travel was more than a politically rationalized addiction or whim, as a previous biographer believed. ${ }^{\mathrm{I} 2}$ From as early as I919, Wilkinson integrated voyages abroad into a distinctively transnational political approach. As with Dora Montefiore's uses of her trip to post-suffrage Finland, Wilkinson provided a human connection between the local and the global for her British political audiences. ${ }^{3}$ Back in Britain, eschewing what she perceived to be the parochialism of British politics, she conjured German refugees or Spanish peasants to life with her anecdotes and first-name acquaintances, bringing far-off troubles within an intimate realm of experience. Rejecting a contradistinction with the non-British "other", Wilkinson incorporated her transnational concerns into her domestic trade-union, political, or campaigning activity. Addressing the issue in her union magazine, she explained that the working class was composed of "thinking individuals [...] not droves or flocks", for whom socialist ideas and international problems stimulated thought and engagement. Whereas her critics wished to close down such discussions, for her these matters benefited the labour movement because the "wider stream of emancipation" sustained the "keenness" of members and the vitality of branches; the alternative was complacency and apathy. ${ }^{\mathrm{I}}$

Nevertheless, the Jarrow MP's “penchant for touring foreign countries”, as a local newspaper uncharitably put it, complicated her politics and her relationship with her constituents. ${ }^{\text {Is }}$ It left her open to criticism from her political opponents as well as grumblings even within the ranks of her own party. She repeatedly rehearsed the case that foreign politics were relevant to her constituents and part of her duties as an MP. ${ }^{16}$ Criticism became particularly intense when travel coincided with unforeseen local political crises. ${ }^{17}$ After Conservatives had sought to make political capital out of one such absence, she retorted that she served the constituency more dutifully than her Conservative Party predecessor ever had. Even within her own

I2. Vernon, Ellen Wilkinson, p. 62.

I 3. Hunt, "Transnationalism in Practice".

14. New Dawn, i9 October 1935, pp. 688-689.

I 5. Shields Gazette, 5 February 1937; Shields Gazette, 23 April 1937.

I6. New Dawn, 27 June 1936, pp. 394-395.

17. Shields Gazette, i० February 1937. 
party, controversy surfaced in the local women's section over Wilkinson's commitment to the Spanish republican cause. ${ }^{18}$

Travel was financially costly as well. ${ }^{19}$ Wilkinson was not typical of transnational women activists. Although university educated, she was not independently wealthy, and hailed from a working-class background. Funding came from diverse sources and could limit her chances to travel. Sometimes, her union, the Labour Party, or government delegated her officially, or campaigns - the Relief Committee for the Victims of German Fascism (RCVGF), the League for Industrial Democracy, or the India League - paid her expenses. A certain amount of resourcefulness and ingenuity was needed at times, through political patrons, selffinanced lecture tours (to the United States in I93I), and journalistic commissions (Germany in February 1936). For the shortfall, she had to rely upon her own salary. Despite its political and financial costs, transnationalism became less a compartment of her political work than a permanent orientation, a state of mind entwined with some of her most mundane activities. By the outbreak of World War II she had developed strong affinities with Germany, Spain, France, India, Ireland, Bulgaria, Finland, the USA, and the USSR.

A transnational orientation also shaped her views on culture. ${ }^{20}$ In contrast to the self-indulgent "Bloomsbury novel" she believed typical of English writing, she held Soviet (and to a lesser extent German) literature and film in deep admiration. Wilkinson's excursions into cultural criticism developed the following themes: the Russian model of proletarian literature; the absence of British literature of working-class life; social contestation as an inspiration for and determinant of literature; the woman subject; the dilemmas of seeking a commercial audience; the compatibility of art and propaganda; and indeed, the revolutionary necessity of a worker's intellectual challenge to capitalist culture. ${ }^{21}$ Signalling her identification with

I8. Jarrow Labour Party Records, Hebburn Labour Women's Section minutes, 20 July 1937. 19. On the gendered question of resources, see Pernilla Jonsson, “On Women's Account: The Finances of 'Bourgeois' Women's Organizations in Sweden, England, Germany, and Canada, I885-1924", in Jonsson, Neunsinger, and Sangster, Crossing Boundaries, pp. I 57-1 86.

20. Though neglected in the scholarship on her novels, see Maroula Joannou, "Reclaiming the Romance: Ellen Wilkinson's Clash and the Cultural Legacy of Socialist-Feminism", in David Margolies and Maroula Joannou (eds), Heart of the Heartless World: Essays in Cultural Resistance in Memory of Margot Heinemann (London, 1995); Ian Haywood, “Never Again?: Ellen Wilkinson's Clash and the Feminization of the General Strike", Literature and History, 8 (1999), pp. 34-43; Laura Beers, "Feminism and Sexuality in Ellen Wilkinson's Fiction", Parliamentary Affairs, 64 (201 I), pp. 248-262.

2 I. Ellen Wilkinson, “The Wage-Worker's Place in Literature”, Plebs (1929), pp. 247-248; idem, "The 'Literature of the Job'", Plebs (1926), pp. I77-179; Pamela Fox, Class Fictions: Shame and Resistance in the British Working-Class Novel, I890-1945 (Durham, 1994); News Chronicle, I3 December 1935. 
the cosmopolitan ideal of the literary world, Wilkinson was also acquainted with figures of international renown: Toller, Alberti, Koestler, Heartfield, Haanpää, Barbusse, Dos Passos, Robeson, and Hemingway. ${ }^{22}$

Moreover, underestimation of her transnational commitments has led to errors in the interpretation of her writings. Thus, her novel The Clash (1929) has been criticized for lacking awareness of colonialism and racism. Her use of the phrase "nigger in the woodpile" has been deployed as evidence of Wilkinson's heroine's casual racism. ${ }^{23}$ Such anachronistic reading stems from the neglect of Wilkinson's long-standing involvement in the cause of colonial liberation and anti-racism. ${ }^{24}$ In December 1920, she had appeared before a US congressional hearing on British atrocities in Ireland. She was also a notable critic of Katherine Mayo's controversial Mother India (1927) that polemicized against Indian self-rule on the grounds of the treatment of women within Hindu culture, and which found considerable resonance among British feminists. Aligning herself with Indian women's organizations and the Congress Party, Wilkinson deemed Mother India a thinly veiled rationalization of Empire. ${ }^{25} \mathrm{Her}$ visit to India in 1932 offers further evidence of her opposition to racism and imperialism. She consequently wrote a series of newspaper articles that exposed British brutality and contributed to The Condition of India report (1933). ${ }^{26}$

Just as her views on culture had transnational terms of references, so too did her conception of historical agency. Existing understandings rightly stress her sympathy for the downtrodden as well as her commitment to the labour and women's movements in the UK. Two qualifications might be made to this picture. Firstly, her sense of agency united these twin commitments through a valorization of humble women that could be articulated in both movements. Thus, in campaigns at home, she transformed suffrage activists, wartime strikers, or housewives during the General Strike into heroines who were making history. Indeed, at the Labour Women's Conference of 1925 , Wilkinson observed that the mobilization of working

22. Peter Wollen, "The Cosmopolitan Ideal in the Arts", in George Robertson, Melinda Mash, Lisa Tickner, Jon Bird, Barry Curtis and Tim Putnam (eds), Travellers' Tales: Narratives of Home and Displacement (London, 1994), pp. 187-196.

23. M. Keith Booker, The Modern British Novel of the Left (Westport, CT, 1998), pp. 307-309; Letter from Ellen Wilkinson to Winifred Holtby, n.d., Winifred Holtby Collection, Hull Central Library.

24. Vernon, Ellen Wilkinson, p. 107.

25. House of Commons Debates, 22 November 1927, vol. 210 , col. 1645-1647.

26. Report of the Conditions in Ireland Made by the Women's International League in American Commission on Conditions in Ireland (Washington DC, I92 I); Monica Whatley, Ellen Wilkinson, Leonard W. Matters, and V.K. Krishna Menon, Condition of India (London, 1933); Daily Herald, 7 December 1932, 3 January 1933, and Is February 1933; Time and Tide, 7 January 1933; New Dawn, 25 February 1933, pp. 79-80. 
women might well be "the deciding factor in modern politics". ${ }^{27}$ Secondly, this attitude was not confined to British politics. Underpinning Wilkinson's internationalism was an idealization of modest women in whom she invested an emancipatory - and often an explicitly revolutionary - hope. This motif recurs in her accounts of Bombay mill girls, dressmakers' picket lines in Cleveland, Spanish peasant women in the movement of land-seizures and collectivization, Parisian shopworkers occupying their department stores, and strikers' wives surmounting the ethnic divisions in New Deal America. ${ }^{28}$ This imbrication of class and women's agency beyond borders and from below is vital to understanding her politics, in particular during its most radical phases. A history graduate, Wilkinson situated this sense of agency in a certain view of history, or a critique of history as it was taught in British classrooms. She reflected that "unselfconscious jingoes" had inculcated generations of British schoolchildren with a "court and army" history and colonial arrogance. ${ }^{29}$ British primacy, for her, was rather a matter of recent geographical accident.

\section{TRANSNATIONAL NETWORKS AND REPERTOIRES}

The concept of the "transnational advocacy networks" has become influential in the study of transnational activism. According to Margaret Keck and Kathryn Sikkink's definition, actors working on a particular issue are bound together by shared values and discourses resulting in dense exchanges of information and services. Such networks can involve actors operating officially or unofficially from a range of institutions. ${ }^{30}$ The transnational activist network creates a set of open fluid relationships with varying degrees of formality and institutionalization. This seems to be an apt framework to understand Wilkinson's transnational activism and she corresponds to the notion of a core networker, not in the sense of being at the network's centre, but because of her vital and multidimensional contribution. Wilkinson fits with a final dimension of Keck and Sikkink's definition, given transnational activity's contribution to the realization of her domestic political goals.

Various international networks facilitated Wilkinson's transnational activities. At the formalized level, she participated in movements of an institutionalized nature. The most obvious of these were the left internationals: the LSI and, while a member of the British Communist Party,

27. Lansbury's Labour Weekly, 5 June I925.

28. Daily Herald, 5 August 1936 and 16 February 1937; New Dawn, 9 March 1935 and 20 March 1937; Time and Tide, I3 February and 20 February 1937.

29. Daily Herald, 9 August 1936.

30. Margaret Keck and Kathryn Sikkink, Activists Beyond Borders: Advocacy Networks in International Politics (Ithaca, NY, I998), pp. 8-10, I4. 


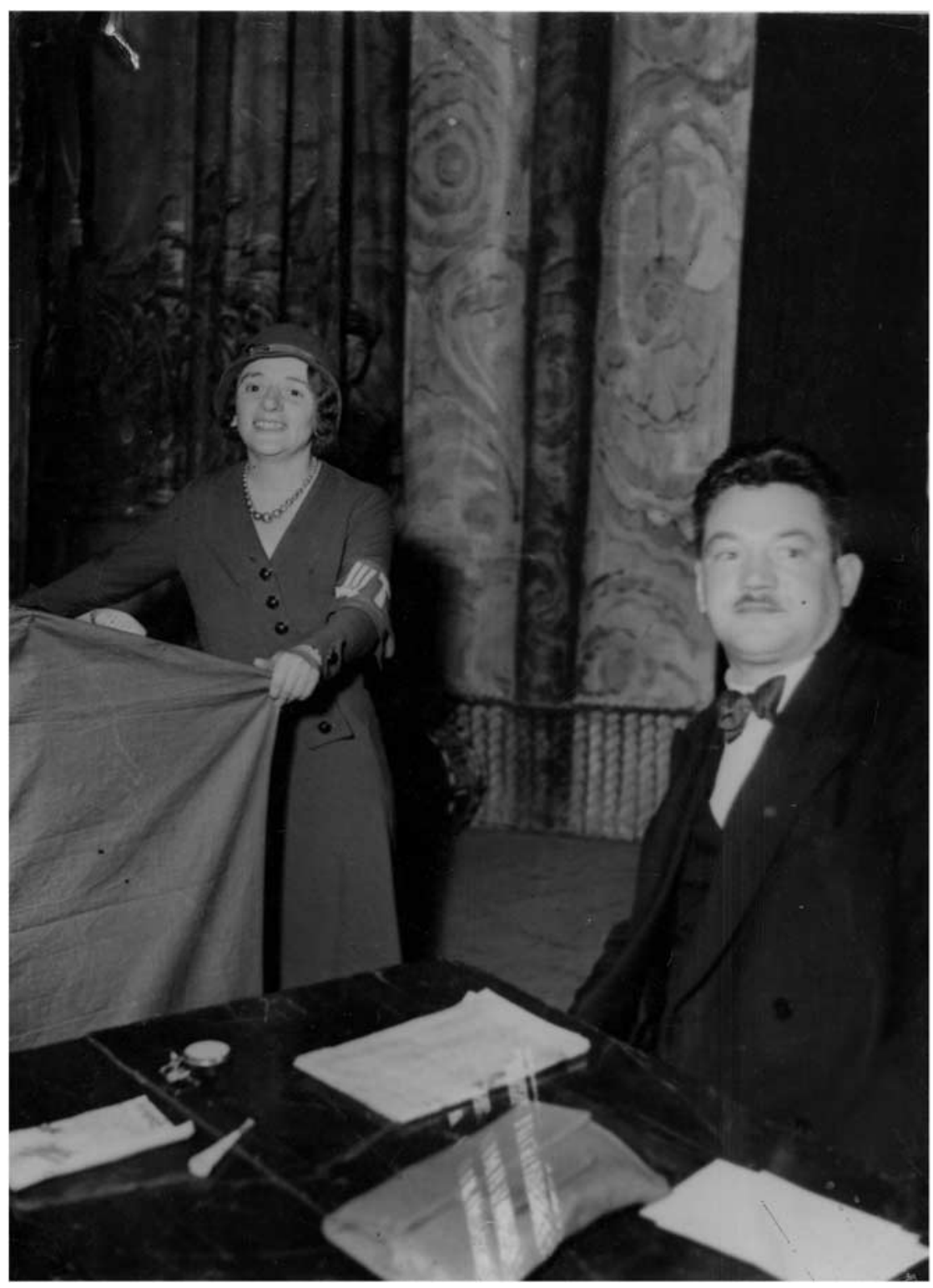

Figure I. Wilkinson with Franz Künstler at an Iron Front rally during the Social Democrat election campaign, Germany, July 1932.

Collection IISH

the Comintern and the Red International of Labour Unions. Similar to the insights provided by Emmanuel Carle's study of Gabrielle Duchêne, Wilkinson bridged (both socialist and communist) labour movements and 
the women's movement in transnational networks. ${ }^{3 \text { I }}$ Her first political travels resulted from her membership of the WILPF, attending its Zurich conference of March 1919, where she emphasized revolutionary or antiimperialist politics in contradistinction to a more minimal programme that could construct a broader feminist consensus. ${ }^{32}$ Wilkinson could act as an intermediary or nodal point between these movements, thereby helping a mutual extension of particular networks. Notable in this regard was the World Congress of Women against Fascism and War which took place in Paris in August 1934. Ellen Wilkinson featured on an initial list of sponsors. This attracted broad support including a number of WILPF activists, despite being linked to the Amsterdam-Pleyel movement and thus an initiative of Comintern circles.

The LSI possessed a highly formalized structure and rigid national demarcations rather akin to the prerogatives of particular unions over different occupations. This formality combined with and reinforced a lack of female representation. ${ }^{33}$ While facilitating Wilkinson's transnational activism through an array of notable contacts in foreign socialist parties or reformist trade unions, the LSI also threatened it. The body discouraged involvement in campaigns initiated by communists such as the League against Imperialism (LAI). ${ }^{34}$ For instance, with a view to disciplining Wilkinson, the Labour Party demanded an explanation from her after a prominent German socialist had complained that Wilkinson, despite her fund-raising efforts, had not sent any funds to the official relief centre in the Saar. ${ }^{35}$

Although Wilkinson engaged occasionally in these formalized institutions of the LSI, she participated in less formal campaigns much more frequently. Thus, while it is true that Willi Münzenberg provided the semi-visible hand of organization behind the LAI or the RCVGF or the World Committee against Fascism and War (WCFW), those involved went well beyond Comintern circles. ${ }^{36}$ Where Ellen Wilkinson is concerned, these less formal

31. Emmanuelle Carle, "Women, Anti-Fascism and Peace in Interwar France: Gabrielle Duchêne's Itinerary”, French History, I8 (2004), pp. 29I-3 I 4.

32. Report of the International Women's Congress, Zurich May I2 to 17 I9I9 (Geneva, I919); Helen Crawford's unpublished autobiography, pp. I 53-I 54, Marx Memorial Library, London; Jo Vellacott, "A Place for Pacifism and Transnationalism in Feminist Theory: The Early Work of the Women's International League for Peace and Freedom", Women's History Review, 2 (1993), pp. 23-56.

33. June Hannam and Karen Hunt, Socialist Women: Britain, I880s to I920s (London, 2002), pp. $176-180$.

34. Jean Jones, The League Against Imperialism (London, 1996).

35. People's History Museum, LP ID CI 27 2i, Marie Juchacz to Jennie Adamson, 30 September 1933 .

36. Willi Münzenberg: Un Homme Contre: Colloque International, 26-29 Mars 1992 (Aix-en-Provence, 1993). 
campaigns that Münzenberg launched, with their dense transfers of information and close interpersonal bonds, come closest to the definition of a transnational advocacy network. Having said this, viewed from the Paris centre of the WCFW, it was her male colleagues Marley and Strachey who were visible in (admittedly incomplete) minutes of discussions, despite her contribution. ${ }^{37}$

Journalist acquaintances provided further contacts that facilitated her political travel. She wrote about the special haunts and fellowship of the foreign correspondents, upon whom she no doubt relied in Germany and Spain, given her limited language acquisition. ${ }^{3}$ They provided her with personal introductions in unfamiliar places as well as insider knowledge and expert diagnosis of events. She claimed that as a result of these friends, together with her local contacts, she was able to transcend the tourist's superficial gaze. With the Spanish Civil War in particular, this circle of foreign correspondents - which included W.N. Ewer, Jay Allen, Louis Fischer, Arthur Koestler, Frederick Voigt, Gustav Regler, Egon Kisch, and Geneviève Tabouis - converged and overlapped with the Münzenberg-Katz network. Paul Preston has explored the complexities of the situations of several of these journalists who straddled professional and political commitments. ${ }^{39}$

Wilkinson's network of journalist acquaintances constituted intermediaries of dense information flows in the cause of anti-fascism, channeling news from various parts of Europe (in particular from the German communist underground, from refugees, and from Spain). This was often achieved in face of the efforts of state repression and censorship to prevent unwanted information passing on to the pages of internationally respected newspapers. Münzenberg's network also had publishing and press agency operations based in Paris in the shape of Editions du Carrefour and later Agence Espagne with which she worked. If Ellen Wilkinson operated within overlapping networks of a more or less institutionalized and public character, she also engaged in a specific repertoire of transnational activism: conference attendance, journalism, acting as a political hostess, missions of investigation, and solidarity.

Wilkinson attended some of the most significant international conferences of her day: WILPF Congresses in I919 and 1929; the International Socialist Student Conference in Geneva, December I9I9; the founding of the Red International of Labour Unions, the third congress of the Communist International and the International Communist Women's Conference in

37. Bibliothèque Marxiste de Paris, Fonds Barbusse 58 s P686 Compte Rendu, I6 January, I-I 5 January 1934 .

38. Time and Tide, 2i December 1935, pp. I898-190I.

39. Paul Preston, We Saw Spain Die: Foreign Correspondents in the Spanish Civil War (London, 2008). 
I92 I; the International Alliance for Women's Suffrage Conference of I 926 in Paris; the first Congress of the League against Imperialism in Brussels in I927; the eleventh Assembly of the League of Nations in 1930; the World Congress of Women against Fascism and War in 1934; the Western European Conference on Spain in August 1936; the International Peace Congress in Paris in $1938 .^{\circ}$ Such events afforded Wilkinson opportunities to encounter activists from other nationalities. Here the question of Wilkinson's agency and gregarious personality is a factor. She renewed acquaintances on her travels beyond the lifetime of the particular campaign that brought her into contact with that individual. She first met Jawaharlal Nehru at the LAI congress of 1927, renewing that relationship on several occasions in relation to Indian independence, his trips to Britain and other campaigns, despite quitting the LAI in December 1928. ${ }^{4}$

Wilkinson's role as a hostess constituted another element in her repertoire of transnational activity. Historiographically, the gendering of British eighteenth- and nineteenth-century high politics has stressed the informal influence of the hostess. ${ }^{42}$ Wilkinson adapted this political practice from the "At Homes" of the wealthy patrons of the suffrage movement, such as Lady Rhondda or Lady Astor. She reframed the practice to fit with her notion of the modern woman whose home was small, easy to maintain, and fitted with labour-saving electrical equipment, to facilitate her entry into the public realm of politics and work. Her frequent parties at her small Bloomsbury flat were both memorable and remarkably cosmopolitan, cementing relationships or making new connections. ${ }^{43}$ Katz, Gandhi, Caballero, Del Vayo, Azcarate, and Nehru were all on occasion guests of honour.

By 1932, journalism became a major aspect of her transnational practice. Wilkinson's political journalism was suffused with her travels. After losing her parliamentary seat in I93 I, journalism drew more of her energies and took a distinctly transnational turn. Hitherto she had written as a parliamentary correspondent, on gender and changing personal mores, and on domestic politics. Increasingly in the course of the I930s, she acted as an impromptu foreign correspondent. The range of Wilkinson's journalism of world affairs is remarkable: most notably, India, the US, Germany, France, Finland, and Spain. In February 1936, in a sensational scoop, she reported Hitler's intentions to militarize the Rhineland within the year. ${ }^{44}$ She provided

40. International Institute of Social History (hereafter IISH) LA IMP LAI Congress manifesto. 4I. Nehru Memorial Museum Library (hereafter NMML), Jawaharlal Nehru papers, Wilkinson to Jawaharlal Nehru, "Wednesday", January 1936, vol. 203, p. 9 I.

42. K.D. Reynolds, Aristocratic Women and Political Society in Victorian Britain (Oxford, 1998).

43. Tribune, i4 February i 947.

44. Sunday Referee, I6 February 1936. 
eye-witness accounts of Gandhi in prison, the land seizures in Toledo in the summer of 1936, the occupation of a Parisian department store during the celebrated strike wave of June 1936, the historic sit-down strikes at General Motors in Flint and Cleveland, and from the trenches defending Madrid. ${ }^{45}$ Such experiences created strong bonds of affinity with the foreign activists that she encountered at these exhilarating and dangerous events. In her journalism, she valorized them as the humble heroes of international struggles.

Such cross-national affinities generated a sense of the transnational interconnection of contentious politics taking place in different parts of the globe. Relaying information on the practices and ideas of these events through her journalism, Wilkinson became an agent of political and cultural transfer, allowing these to be assimilated into a British idiom. ${ }^{46}$ Thus, it is surely no accident that the Jarrow Crusaders should contemplate a sit-down strike in Parliament after Wilkinson had written and spoken about her experiences in the Parisian occupations only weeks before.

Her journalism also facilitated information flow within transnational networks and she acted as a local intermediary for them with the British press. She published in a wide variety of publications (including several mass-circulation dailies such as the Daily Express, the Daily Herald, the Daily Mail, and the Evening Standard) and had long-standing relationships with editors such as Kingsley Martin at the New Statesman, Lady Rhondda at Time and Tide, and J.P.M. Millar at Plebs. It was for good reason then that the India League were "specially anxious" to persuade Wilkinson to visit India, privately recognizing her talent for publicity as well as her British and American press contacts. ${ }^{47}$ She played a similar brokerage role with publishers, easing the way for the publication in Britain of The Brown Book with Victor Gollancz and advising Nehru on where to publish. ${ }^{48}$ She was also able to secure a special issue on Spain in Time and Tide.

The missions of investigation entailed a fourth gendered mode of Wilkinson's transnational repertoire. She embarked on such missions in order to witness injustice, or repression, or even atrocity: to Ireland

45. Life magazine, is February 1937, p. i6.

46. Ann Thomson, Simon Burrows, and Edmond Dziembowski (eds), Cultural Transfers: France and Britain in the Long Eighteenth Century (Oxford, 2010), pp. 2-3; Michel Espagne and Michael Werner, Les Relations Interculturelles dans l'espace franco-allemand (XVIIIe et XIXe siècle) (Paris, I988).

47. Newcastle University Special Collections, T.D.W. Reid Collection, Home Political 1932 40 XII, p. 2, M.G. Hallett to Sir Samuel Findlater Steward.

48. World Committee for the Victims of German Fascism, The Brown Book of the Hitler Terror and the Burning of the Reichstag (London, 1933). 
in 1920 , to Bulgaria in 1925 , to India in 1932, and to Spain in 1934 and April 1937. On such travels, she was obliged to establish her claim to truthfulness and deny being indebted to her hosts. Some of these missions emphasized their non-political and humanitarian purpose. It was to underline this point that the delegations to Ireland, Bulgaria, and Spain in April 1937 were exclusively composed of women (the last case was even described on occasion as a religious delegation). ${ }^{49}$ Wilkinson often acted as a broker between the discrete transnational networks of women's movements, reformist labour organizations and communists.

Opponents framed these visits very differently. For them, this "political tourism" was little more than foreign interference, hypocrisy, superficial partisanship, or conducted tours. ${ }^{50}$ Sir Samuel Hoare dismissed Wilkinson's investigation into Indian conditions as a "Potemkin tour". Wilkinson responded that this "perfect excuse of the ages" was intended to deflect her charges of police brutality and to ignore the loss of consent for British rule. ${ }^{\text {I }}$ Behind the scenes, the British and Indian governments gathered evidence to discredit the delegation. Nonetheless, one confidential note admitted that Wilkinson's claims about police abuses that she had witnessed at Mardan had to be taken as truthful, despite diverging from the account of the local police. Indeed, ironically enough, the authorities did precisely what they accused Congress of. They provided political guides for the delegation, lined up interviews with officials, resisted inspections of prisons and gave special instructions to the police in the areas that the delegates were visiting. British and Indian officials therefore sought to limit and influence the delegation, seeking in the words of one report to keep them "on the leash". Likewise, while Luis Bolín, the $A B C$ journalist and later Franco's notorious foreign press secretary, sought to discredit Wilkinson's trip to the Asturias in the British and the international press, Álvarez del Vayo, Minister of Foreign Affairs during the Spanish Civil War, insisted that the Asturian visit had had the positive effect of preparing the way for wider international solidarity for republican Spain..$^{52}$

These missions do pose a methodological question about the degree of cultural incomprehensibility and political naivety. Much of the literature about conducted tours has been concerned with the journeys of Westerners to the Soviet Union. David Caute identified the principal features of the conducted tour, whereby the regime carefully constructed itineraries,

49. Monica Whately, "Catholic Spain as I Saw It", Woman To-Day (June I937), pp. 7 and I 5. 50. Congreso de los Diputados, I4 November 1934, pp. 4749-4750; José María Gil Robles, No Fue Posible La Paz (Barcelona, 1968), pp. I 52-1 53.

51. Star, 2 December 1932; Whatley, Wilkinson, Matters, and Menon, Condition of India, pp. IO-II.

52. Luis Bolín, Spain: The Vital Years (London, 1967), pp. I30-137; Preston, We Saw Spain Die, pp. I 57-164; Julio Álvarez del Vayo, Les batailles de la liberté (Paris, 1963), p. I84. 
flattered their guests, and closely observed interactions with Soviet citizens. ${ }^{53}$ Overall, most scholars agree that such tours reinforced assumptions rather than simply hoodwinking visitors. Self-deception was as important as official manipulation. It is surely significant that Wilkinson did not enter into print about her 1937 trip to the Soviet Union (departing from her habitual practice), signalling both a reluctance to endorse the regime and an uncertainty about its direction, symptomatic of others in the Münzenberg network. ${ }^{54}$ Hugo Garcia has scrutinized the motives and perspectives of foreign visitors to the Spanish Civil War through a culturalist lens. For him, travellers like Wilkinson were trapped in their cultural stereotypes about the Spanish character (the barbarous "black" or the romantic "pink" legend).55 Similarly, Nicholas Owen identified the British left's inclination to support Nehru rather than Gandhi as a consequence of its metropolitan presumption. ${ }^{56}$ While praising Gandhi's courage and his indispensible contribution to building a mass movement, Wilkinson certainly inclined towards Nehru in this way.

But such culturalist approaches, stressing the mutual incomprehensibility, prejudices, and assumption of superiority underplays the complexity of the transnational contentious politics at the micro-level. While it is true that Wilkinson sometimes engaged in stereotypical idealizations of the Spanish people as heroic republicans, or equally talked of Indian spirituality, the danger is that her pro-republican or anti-imperialist propaganda and movement-building are taken for her private analysis, which was actually more nuanced and shrewd. Her support for Nehru was strategic both on cultural grounds (being most comprehensible to her British audience) but also on political grounds, believing - rightly or wrongly - that his politics was more suited to transnational movements of contestation against the global capitalist order.

A consequence of Wilkinson's transnational advocacy was that she deployed devices to establish a commonality of purpose, a mutual comprehensibility, and frames that could build transnational movements. It is for this reason that she proposed transnational categories of identification such as heroes, youth, trade unionists, women, and class. Equally, she circumvented cultural difference by subverting alterity: when in India she described herself as an English untouchable for being a trade unionist, or a shop workers' union organizer in a striking Parisian department store. Even her opponents in the security services noted her exceptional talent for popularizing the Indian cause with British audiences.

53. David Caute, The Fellow-Travellers: A Postscript to the Enlightenment (London, 1973).

54. Leah Manning, A Life for Education (London, I972), p. I I2.

55. Hugo García, "Potemkin in Spain? British Unofficial Missions of Investigation to Spain during the Civil War", European History Quarterly, 40 (2010), p. 218.

56. Nicholas Owen, The British Left and India: Metropolitan Anti-Imperialism, I885-1947 (Oxford, 2007). 
The solidarity mission might constitute Wilkinson's final mode of transnational activism. In some ways, her trips to India in 1932 and Spain might be considered in this light, with the obvious goal of publicizing the cause of those with whom Wilkinson sympathized. Other trips were more clearly concerned with solidarity work rather than propaganda or investigation. Her 1926 trip to the United States to raise funds for striking British miners provides the most well-known example of this. ${ }^{57}$ Antifascist solidarity prompted a number of trips such as the one to Madrid with Henri Barbusse to establish the RCGVF there. She also travelled to intervene on behalf of political prisoners: Thälmann in Germany in 1934, and Antikainen in Finland in 1935. This found its equivalent at home when Wilkinson conducted transnational solidarity work for such campaigns as the Soviet famine victims or the Meerut prisoners.

\section{EXPLAINING AN INTELLECTUAL AND POLITICAL ITINERARY}

Transnationalism illuminates the radicalizations, drifts, and reversals of Wilkinson's political and intellectual trajectory in a new way. Principally, two radicalizations disrupt smoother narratives of her political development. A first radicalization was connected to World War I and the Russian Revolutions of 1917. Kevin Morgan identified the widespread sympathy for the Bolshevik regime inside the Labour Party as a peculiarity of the British left all too easily overlooked in the historiography of labour as it emerged after $1945 .{ }^{58}$ Wilkinson fits within this mould. She reflected that her Soviet summer of I92 I had transformed "so many" of her "views and opinions".59 For "the European revolution" to succeed, Russia needed to survive as it was the "front-line trench in the class war". 60

This radicalizing experience had class and gender implications. Wilkinson reported enthusiastically on the situation of working women in Soviet Russia. ${ }^{61}$ In the realm of political, economic, and reproductive rights, "women revolutionaries had stamped their ideas on the new regime, and women in Russia to-day have been given the most complete freedom that

57. Daily Herald, i7 August 1926.

58. Kevin Morgan, Bolshevism and the British Left: Labour Legends and Russian Gold (London, 2006).

59. Rossiiskii gosudarstvennyi archiv social'noi i politicheskoi istorii (the Russian State Archive of Socio-Political History, RGASPI), f 495 op 2 d 35 Questionnaire, no. 407, 24 July I 92 I; RGASPI Pervyi mezhdunaroldnyi congress revoltiutsionnykh professional'nykh i proizvodstveennykh soyuzov. Stenograficheskii otchet, 3-19 Iyuliia 1921, 17, pp. 57-6I; The Communist, 27 August I $92 \mathrm{I}$.

60. Ellen Wilkinson, "Help Russia”, Labour Monthly, September I92 I, p. 2 I4.

61. Idem, "The Women's Movement in Soviet Russia", Communist Review, November I92 I, pp. 26-29. 


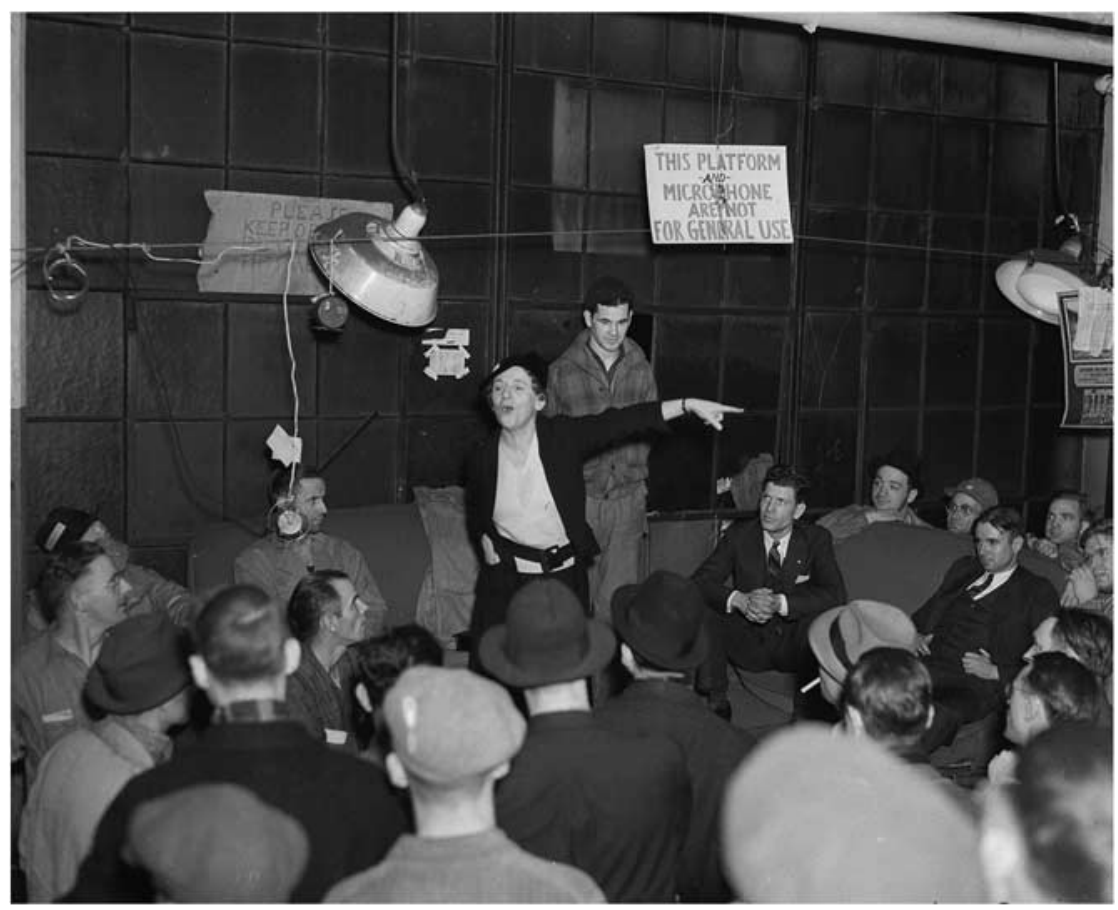

Figure 2. Wilkinson addressing sit-down strikers at General Motors in Flint, Michigan, January 1937. Reporter/AP. Used with permission.

legislation can bestow". She greatly admired Alexandra Kollontai for this work but also for her contributions to the debate on the New Economic Policy. Aligning with Wilkinson's own view of working women, Trotsky's opening speech at the women's congress greatly impressed her. He predicted that revolution would transform women into the most revolutionary section of the working class. From the perspective of her intellectual development, World War I and the October Revolution changed Wilkinson into a revolutionary, and her association with communism lingered until 1939. At a practical level, her visit to the famine region was the beginning of a longstanding relationship with Münzenberg's Workers' International Relief and his other networks. ${ }^{62}$

Wilkinson's second radicalization (1932-1936) followed events in Germany and Spain and has been generally overlooked. Linguistic markers of her earlier radicalization - "class struggle" and "revolution" - that had 
largely fallen out of her vocabulary returned to her writing and platform rhetoric. While her trip to India in 1932 reconfirmed her anti-imperialism (telling Indian students that she was ashamed to be British), German events alerted her to the transnational threat of fascism. ${ }^{63}$ Her response was that working-class unity and socialist revolution were needed to prevent this occurring. Simultaneously, a cultural backlash against women, in part as a consequence of the Depression, radicalized her gender politics. She railed against a "silent but invincible sex-freemasonry of men", and a "hidden but bitter sex-struggle" ${ }^{64}$ She perceived this resurgent domestic anti-feminism in the light of the success of Nazi movement. She brought the two issues together with public meetings for British feminist organizations, telling of her experiences in Germany.

The transnational approach not only adds to our understanding of her political radicalization, it also redefines her relationship with state authority. She defied conventional boundaries of citizenship and this became more pronounced during her second radicalization. She used her political leverage with those in positions of influence to secure visas for those officially deemed to be undesirable. Consequently, she provided an indispensible service for those conducting subversive politics across British or imperial borders. Thus, she intervened in parliament on behalf of individuals in the nationalist movements in India and China. ${ }^{65}$ Indeed, the intelligence services worried that Wilkinson amongst others would "provoke a storm" in parliament if a visa was denied to Mrs Sun Yat Sen. ${ }^{66}$ British intelligence also discussed the denial of visas to members of the League against Imperialism (LAI). Indian Political Intelligence, consulting with Scotland Yard and SIS, suggested a provisional black list of six British subjects (among them Wilkinson) and seventeen "aliens". ${ }^{67}$

Crucial to her sharpened defiance of the norms of citizenship was her relationship with Otto Katz, Münzenberg's right hand man. He was the most important instance of someone whose transnational activism Wilkinson facilitated. ${ }^{68}$ Her work with Katz developed as a consequence of her involvement in the RCVGF and the Reichstag counter-trial. She acted as intermediary between the Paris centre of operations and the politicians, intellectuals, publishers, and lawyers involved in its work

63. Stefan Berger, British Labour Party and the German Social Democrats, I900-I93 I (Oxford, 1994), p. 245 .

64. John Bull, 26 March 1932.

65. House of Commons Debates, 7 July 1926, vol. 197, col. 2070-2071; 8 March 1927, vol. 203, col. I1 $97-1202$.

66. British Library (hereafter BL), Indian Police Files (hereafter IPF), P and JS 2045, Minute paper.

67. BL, IPF P and JS 2042, Minute paper: R. Peel, "Action to Be Taken against Members of the League against Imperialism”, 2 I December 1927.

68. Jonathan Miles, The Nine Lives of Otto Katz (London, 2010). 
in Britain. The relationship deepened with the Spanish Civil War. On 4 August 1936, Katz visited the UK to help orchestrate the propaganda campaign in favour of the Spanish republic and was to return on at least twelve occasions during the Spanish Civil War. Based in Paris, he was also a frequent visitor to Spain, SIS describing him as a Comintern courier between Paris and Spain. Wilkinson was instrumental in securing Katz's entry permits, despite him having been put on a special blacklist prompted by a Home Office circular of 5 August $1933 .{ }^{69}$ Indeed, Wilkinson's repeated interventions and Katz's frequent visits caused both consternation among the security services as well as tension between them and the Home Office. ${ }^{70}$ The security services had made three strong but unsuccessful representations to the Home Office to prevent Katz's entry. ${ }^{7 \mathrm{I}}$

Wilkinson also assisted in securing asylum for political refugees. The events of the late I930s had human consequences for the transnational networks in which she was involved. In the aftermath of the Munich conference, Prague, where many German refugees had settled, was no longer safe. Katz asked Wilkinson to obtain visas for twenty-five refugees, principally German communist former Reichstag deputies. Most notable amongst these were artist John Heartfield and Wilhelm Koenen. ${ }^{72}$ The defeat of the Spanish republic had a similar effect. German communist author and international brigader Alfred Kantorowicz remembered Wilkinson's friendship and her help in securing his flight to safety after the Spanish Civil War. ${ }^{73}$ She also helped German communist Hans Kahle (the commander of the Eleventh International Brigade, whom she had encountered in her April 1937 visit), to get British and French visas, writing to the French Interior Minister on Kahle's behalf. ${ }^{74}$

Wilkinson's participation in this network increased the British state's scrutiny of her activities. The security services kept a "personal file" on her: $\mathrm{PF}_{421}$ 36. While files on her contemporaries such as Cripps, Laski, and Brockway have now been released, hers was destroyed in 1946 when she was

69. The National Archives (hereafter TNA), $\mathrm{KV}_{2} \mathrm{I}_{3} 84$ I86, Geoffrey Lloyd to Wilkinson, I4 July 1936.

70. TNA, KV2 I 384 i 83 a, DSS report (S8), 26 June 1936.

7I. TNA, KV2 I384 28 Ia, Report on Katz, 2i November 1938; TNA, KV2 $\mathrm{I}_{3} 84$ 303 Metropolitan Police report, i I April 1939.

72. TNA, KV2 1062 I60a: Wilkinson to Katz, i 8 November I938; TNA, KV2 1384 300, letter to Vivian, 20 February 1939, with extract of letter, Wilkinson to Katz, Io February I939; TNA, $\mathrm{KV}_{2} \mathrm{I}_{3} 84$ 284b, summary Wilkinson to Katz, 8 December I938; TNA, KV $2 \mathrm{I}_{3} 84{ }_{2} 83$ c, summary Fischer to Katz, 6 December 1938.

73. Alfred Kantorowicz, Exil in Frankreich: Merkwürdigkeiten und Denkwürdigkeiten (Bremen, I97I), pp. 69-70, 226.

74. TNA, KV 2 I 384284 b, summary of intercepted letter, Wilkinson to Katz, 8 December 1938 ; TNA, KV2 I 384 283c, summary of letter Fischer to Katz, 6 December I938; Charlotte Haldane, Truth Will Out (London, 1949), p. 178. 
Minister of Education. ${ }^{75}$ Cross-referencing other files, the correspondence concerning her trip to India, the Reichstag fire trial, and other campaigns were intercepted, though the scale of this practice in relation to Wilkinson is unknown. It may be that British Intelligence monitored all her correspondence and reported on her telephone conversations during the i930s. Not only was she under surveillance from the British state but she was also either investigated or under surveillance on some of her travels abroad.

Consequent upon her defiance of the conventional boundaries of national politics, and the attention that she drew from the authorities, several instances exist of Wilkinson engaging in subterfuge. On her trip to India, she changed her itinerary at the last minute to frustrate the police, slipping away from her "guide" to access aspects of Indian life that she was not meant to see. When she was interviewing witnesses in Takkar, the site of a massacre of non-violent protesters two years earlier, she asked the plain-clothes police officer who was taking notes to leave. ${ }^{76}$ During Otto Katz's visit to London to promote The Brown Book, Special Branch officers complained of Wilkinson's driving because she had managed to give her tail the slip. ${ }^{77}$ In 1936, she even telephoned her editor with a newspaper article from under the bedcovers of her hotel room in Berlin.

The period of her second radicalization was situated in a wider pattern of contestation: a transnational wave of anti-fascism with Spain at its epicentre, just as Russia had been the focal point of the previous wave of transnational social contention. Indeed, Wilkinson had a remarkable record of glimpsing some of the most significant and intense moments of contestation in these years: the Nazi seizure of power, the Asturias in 1934, the French workplace occupations of 1936, the General Motors sit-down strikes, and the defence of Madrid. She understood these events to be interconnected and sought out "the class war across the world" ${ }^{8}$ Thus, for her, the Asturian miners' insurrection was "the first serious check to the fascist wave in Europe" ${ }^{79}$ The effects of this transnational cycle of contestation upon Wilkinson can be identified in her overall political outlook: defeat in Spain and the looming war prompted a sharp reversal in her political demeanour. As social movement scholars have noted, waves of contestation entail an emotional cycle. ${ }^{80}$

75. TNA, KV 2598 35B, Superintendant Canning, Special Branch note, 30 June 1933.

76. BL, IOR L PJ I 2448 , secret CID report: visit to NWFP of Wilkinson and Menon, for 9 to Is October 1932, I8 October 1932.

77. TNA, KV 2 I $_{3} 82$ 46b, Special Branch to MI5, 3 July i933, pp. 2-3.

78. New Dawn, 20 March 1937.

79. Ellen Wilkinson, "Terror in Spain", Nation, 6 March 1935, pp. 232-233; Ernest Hemingway's preface recorded this shared emotional cycle: Gustav Regler, The Great Crusade (New York, 1940).

80. Jeff Goodwin, James M. Jasper, and Francesca Polletta, "The Return of the Repressed: The Fall and Rise of Emotions in Social Movement Theory", Mobilization, 5 (2000), pp. 65-83. 


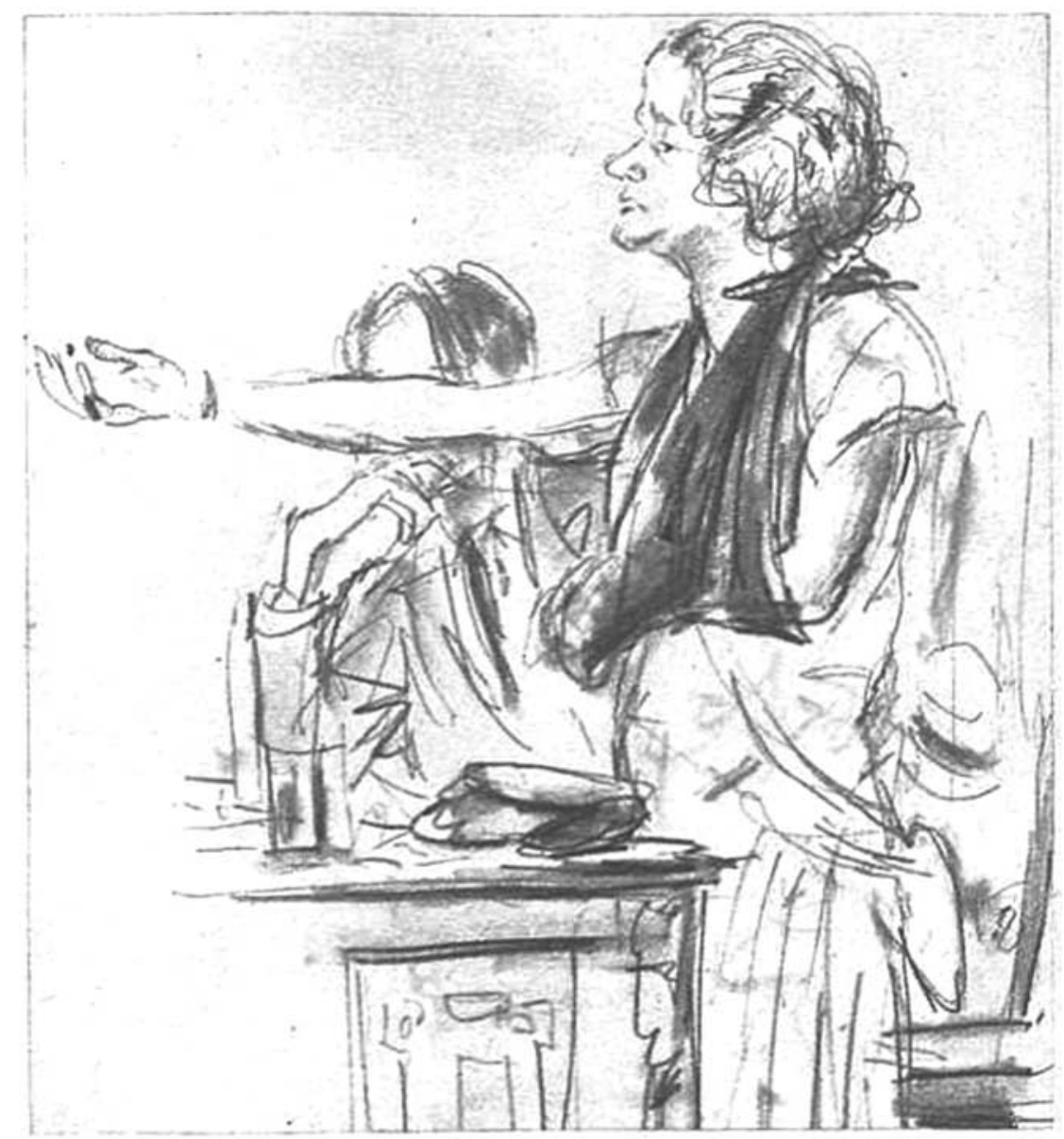

Figure 3. Arteche's sketch of Wilkinson speaking at El Ateneo, Madrid, during a visit with Barbusse and Lord Marley in July 1933.

Biblioteca Nacional de España. Used with permission.

While in public a brave face was put on Spanish events, Wilkinson's journalism and private correspondence are suffused with the emotionality of contention, with a profound oscillation between optimism and deep despair. For her, Spain - that in 1936 had been the "hope of the world" - was "draining me dry" by late 1938 . $^{8 \mathrm{r}}$ She was not alone in this. Reminiscing in 1947, Kantorowicz remarked how the outbreak of war had broken up the network of communists and their closest anti-fascist collaborators amongst

81. Daily Herald, 5 August 1936; TNA, KV 2 I $_{3} 84$ 280, Ellen Wilkinson to Otto Katz, n.d., late October-early November 1938. 
whom he counted Wilkinson. He recalled their shared emotional reaction to events: a growing collective despair that Europe was not heeding their warnings during the later I930s, and by the summer of 1938 they sensed that it was already too late. He observed that they were bound together in an abiding friendship and a deep common spiritual distress. ${ }^{82}$ Her letters to Katz and Fischer disclose a deep respect and emotional attachment to several members of this group. These affective ties of a "transnational political community" sharing the demoralization of defeat provides the affective backdrop to Wilkinson's political reorientation in $1939-1940{ }^{83}$

To borrow Philippe Burrin's heuristic device for political itineraries, Spain also signalled her "drift" towards the "field of force" of conventional British labourism from an anti-imperialist revolutionary position to a reformist (and distinctly Fabian) one. ${ }^{84}$ A letter to Nehru in March 1936 shows her earlier anti-war and anti-imperialist position beginning to drift. She states that, in the aftermath of the march into the Rhineland, she finds the returning rhetoric of a war to save democracy "ghastly"; it is all so redolent of I9I4. With anti-fascists now mistakenly looking to France to destroy Hitler, she feared that the labour movement would swing to jingoism. She agreed with Lansbury on the need to "warn workers against slaughtering each other in further imperialist quarrels". 85

Her membership from autumn 1937 of the Labour Party NEC, with its reformist and electoral horizons, contributed to her growing moderation (as it had in 1927-1929). Indeed, several aspects of this transition entwined: an unacknowledged shift from anti-imperialism to democratic/ progressive military alliance and from being anti- to pro-rearmament. In Spanish terms, she veered from support for working-class and peasant insurgency to a largely uncritical support for the Negrín government while it dismantled collectivization in the factories and on the land. In terms of anti-fascist alliances, Wilkinson abandoned the strategy of a "united front" of working-class forces that she articulated between 1933 and I936, adopting (in late 1936 or early 1937) the Popular Front position held inside the Comintern from the summer of 1935 , and by her colleagues on the British left in the Unity Campaign. ${ }^{86}$

One of the contradictions disrupting contemporary political bearings was the relationship between the Soviet Union and Spain. The Spanish Civil War coincided with show trials and purges in Moscow, and several

82. Alfred Kantorowicz, Deutsches Tagebuch (Munich, 1959), pp. 339-340.

83. Clavin, "Defining Transnationalism".

84. Philippe Burrin, La dérive fasciste: Doriot, Déat, Bergery, 1933-1945 (Paris, I986).

85. Jawaharlal Nehru, A Bunch of Old Letters (London, I960), letter dated 22 March 1936, pp. $176-178$.

86. Ellen Wilkinson and Edward Conze, Why Fascism? (London, 1934); idem, Why War? (London, 1934). 
in Wilkinson's network such as Münzenberg, Fischer, Regler, and Koestler were privately registering their profound unease about events there; each ultimately had what Koestler called their own "Kronstadt" moment. ${ }^{87}$ Wilkinson could not help but notice the political itineraries of those she had spent time with in British and foreign climes. It is surely no accident that several of these figures became prominent Cold War anti-communists.

Disillusion and ruptures occurred by other routes. Alienated by his Spanish experiences and the British left, Conze abandoned Marxism in I 938 and gravitated towards Buddhism. ${ }^{88}$ Toller committed suicide in New York on 22 May 1939. Münzenberg and the Comintern grew apart. He visited Moscow at the time of the Zinoviev show trial in September 1936 and came under suspicion of Trotskyism. To avoid a summons to Moscow, he went into hospital in I937. He was expelled from the German Communist Party in May i938. In that October, he established with social democrat Rudolf Breitscheid an anti-Stalinist newspaper for German socialists, Die Zukunft. In October I940, some months after his death, Münzenberg's strangled body was discovered in woods near Saint-Marcellin (Isère), with a rope around the neck. ${ }^{89}$ Wilkinson's friends Victor Schiff and George Catlin both believed that Stalin was implicated in Münzenberg's death..$^{\circ}$

The Labour Party NEC argued that all campaigns involving the Comintern constituted hollow fronts and manipulated the gullible. Indeed, this is the conclusion of an earlier biographer of Wilkinson, even before the revelations of the Soviet archives and the release of MIs files. Certainly Wilkinson's reputation for honesty was used to promote anti-fascist propaganda, some of it fabricated. She was a perennial member of what Münzenberg called his “innocents' club” in its various incarnations. Yet she was no naïve liberal, agreeing as she did to the necessity of both political violence against the Nazis and counter-propaganda. She even shared a knowingness about such activity, describing as "bourgeois celebrities" those she invited to her cocktail party to promote The Brown Book.

Historiographical emphasis upon an instrumentalization of intellectuals may lead to an unwarranted dismissal of the longer-term significance of the LAI for anti-colonialism, or of the work of the WCFW in exposing the nature of the Nazi regime at a time when the democracies adopted a

87. Gustav Regler, The Owl of Minerva (London, 1959), pp. 230-267; idem, Great Crusade, pp. I89-2 19; Arthur Koestler, The Invisible Writing, vol. II of Arrow in the Blue: An Autobiography (London, 1954, also repr. 2005), pp. 382-392; R.H.S. Crossman (ed.), The God that Failed (London, 1950), pp. 74-81, 220-225.

88. Edward Conze, Memoirs of a Modern Gnostic (Sherborne, 1979), pp. I 8-20.

89. TNA, KV 2774280 A, report 20 December 1940 on intercepted letter from Babette Gross to Edo Fimmen, 7 November 1940.

90. George Catlin, For God's Sake, Go: An Autobiography (Gerrard's Cross, 1972), p. I 47. 
strategy of accommodation and normalization of diplomatic relations with Hitler. ${ }^{91}$ These bodies were more than mere instruments of communist recruitment and control. Although there was a considerable degree of behind-the-scenes management, they were established on common ground and espoused shared goals with those beyond communist ranks. Wilkinson was aware of the extent of communist involvement and was willing to cover for this in the face of hostility from the press and the reformist left. Her calculation was that it was better to be involved with such campaigns alongside communists than rely exclusively on the Labour Party and the LSI, whose record on such matters she deemed to be hardly inspiring.

Jacques Rancière has suggested that travel can transform utopian identification into its reverse: a loss of one's way, a "refiguration in which one becomes a stranger to oneself". ${ }^{92}$ Wilkinson's transnational experiences and activities occasioned just such a transformation. It had its roots in her experiences of Spain but was connected to a sequence of events that brought together Spanish defeat, the Hitler-Stalin Pact, and the Soviet invasion of Finland. The Winter War prompted her to sever her connections with Popular-Front-style campaigns, such as the Labour Research Department and Tribune. ${ }^{93}$ Moreover, the transnational perspective provides an index of her political reversal of I939-1940. Over Indian independence and the Empire, the League of Nations, the conduct of war, the bombing of civilians, and the nature of the Soviet Union, Wilkinson's outlook changed profoundly. Some contemporaries such as Leah Manning and Chuter Ede noted this metamorphosis, but for some she was remembered in essentialist form: "Red Ellen". When the change was alluded to, it was usually explained in terms of influential men, either Morrison or Churchill, or on the grounds of careerism. Nevertheless, the radical reputation that Wilkinson had earned through her transnational politics remained vital for her political career. Churchill included her in his cabinet precisely to show that his government stretched to the far left of the Labour Party. With special responsibility for air-raid shelters and civilian defence during the Blitz, the "shelter queen" was deployed to legitimize the "People's War". More than any figure in cabinet, she had the popular appeal to allay working-class grievances.

Neither her transnationalism nor her internationalism halted with exalted office, but both did mutate: she traversed the divide between

91. Roeslan Abdulgani, The Bandung Connection: The Asia-Africa Conference in Bandung in 1955 (Singapore, I98I), pp. I69-180.

92. Jacques Rancière, "Discovering New Worlds: Politics of Travel and Metaphors of Space”, in George Robertson et al. (eds), Travellers' Tales: Narratives Of Home and Displacement (London, I994), pp. 36-37.

93. TUC Library, LRD i B I i I, executive minutes, 6 May i940; John and Mary Postgate, A Stomach for Dissent: The Life of Raymond Postgate, I896-I97I (Keele, 1994), p. 209. 
transnational networks of contentious politics and the transnationalism of high office. The latter entailed ministerial visits, spells of convalescence in Switzerland, and participation in the constitution of intergovernmental institutions. Crossing a line between global contentious politics and its management, Wilkinson was an official delegate to the San Francisco United Nations Treaty Conference (April-June 1945, being prominently associated with its Women's Charter) and chairperson of the inaugural meeting of the United Nations Educational Scientific Cultural Organization (November 1945). While older conventions in the historiography of global governance have focused on ideological or institutional matters, Wilkinson's journey to such responsibility is unexpected and non-linear. Thus, Wilkinson fits well with Mark Mazower's reinterpretation of the San Francisco conference. He teased out complex micro-level interactions between ideas, individuals, and the structures of power. ${ }^{94}$ According to him, the intellectual pre-history of the UN that emerges, like this study of Wilkinson, is one of paradoxes, reverses, and unexpected continuities.

Just as from 1939 her transnational practice reconfigured, so did her internationalism. After June I940, she adopted a world view of AngloAmerican moral leadership, with distinct inflections of Churchillian patriotic war rhetoric. After exculpating those Germans who had never voted for Hitler in the early stages of war, her attitude changed, saying of RAF raids on German cities, "the rest of the world knows that they started it and are only getting back what they gave". ${ }^{95}$ Her internationalist impulses were rechanneled. ${ }^{6}$ Her reading of international relations moved from realism to idealism, from structuralism to humanism, and from Marxism to a liberal rights discourse. Her focus drifted from the structural forces of imperialism as the cause of war to an idealist logic of the inculcation of a new generation in a culture of peace-making. As Minister of Education, she articulated UNESCO's new global mission, of which she was a significant architect. ${ }^{97}$ In addition, towards the end of her life, with the wartime grand alliance broken apart, she sought to promote British culture in eastern Europe in early Cold War efforts to marginalize Soviet influence with a trip to Prague and one planned to Belgrade. ${ }^{9}$ Furthermore, her renegotiation of nationalism and internationalism also had implications for her attitude to Empire: she dropped her outright opposition to British imperialism, upbraided Harold Laski

94. Mark Mazower, No Enchanted Palace: The End of Empire and the Ideological Origins of the United Nations (Princeton, NJ, 2009).

95. Perth Advertiser, 8 August 1943.

96. The Times, I9 January 1946.

97. Her foreword in UNESCO: What It Is and What It Does? (London, 1946).

98. Borthwick Institute, York University, Halifax A2 27858 3, Sir Charles Peake to Earl of Halifax, 28 February i955. 
for calling Britain a second-rank power, and even called in cabinet for Gandhi's imprisonment in June $1946 .{ }^{99}$

The construct of "Red Ellen" stresses the continuity of her politics, presenting her principally within the framework of British and left Labour politics. By widening the spatial horizons of biographical study, this article has problematized such a narrative. It has brought into greater relief the two most radical phases of her politics (in the aftermath of World War I and after Hitler's accession to power). Her passing support for revolution sits uneasily with the British Labour tradition and has been resisted in memorialization and in the historiography. Consequently, her metamorphosis in 1939-1940 has not been fully appreciated. Both the Churchill and Attlee governments needed to trade on and maintain her credibility as a radical for popular consumption in order to legitimize the "People's War" and the "Golden Age of Labour". Despite her many attributes, this was the secret of her success, explaining her exceptional attainment of high office as only Britain's second woman minister.

Finally, one woman's role in the transnational networks of the interwar years has disaggregated changes in ideas, personal relationships and practices. It thereby reintroduces the complex micro-interactions of these ideological, practical, and human dimensions. From 1919, Wilkinson slowly began to accumulate contacts of transnational scope. She mediated what might otherwise be assumed to be more or less discrete feminist, socialist, pacifist, cultural, and communist networks. Although these networks might look relatively stable at the macro-level, this - in her case at least - masked changing multifaceted relationships with networks: entering, brokering, connecting, switching, or exiting them. Her ideas mingled, radicalized, or drifted in the transnational spaces these networks created.

Conditioning these changes in her ideas, practices, and relationships with networks were waves of social contestation with crucial affective and cognitive dimensions that subtly altered the climate of ideas and political mood. These gradual processes gave way to sudden dramatic mutations in both her transnational practices and her political internationalism, coinciding with new phases of internationalism in 1939 and 1945 . The coincidence of the reversal of Wilkinson's politics and the epochal rupture of 1939-1940 is an intriguing dimension of this case study. As scholars of transnationalism have noted, biography starts with high orders of magnification but ends with insights into broader patterns. ${ }^{100}$ Judging by Wilkinson's circles, this epochal rupture destabilized transnational networks and transformed ideas. While far from being uniform, there were identifiable patterns of clustered

99. TNA, CAB I95 4, Cabinet Notes, s June 1946, pp. $232-233$.

I00. Bernhard Struck, Kate Ferris, and Jacques Revel, "Introduction: Space and Scale in Transnational History”, International History Review, 33 (20I I), pp. 573-584. 
trajectories within the activist networks. By slightly widening the focus, several of Wilkinson's acquaintances who moved from communism to anti-communism come into view; ultimately they became key figures in the cultural Cold War.

It is not only the level of internationalist ideology but also that of political power that needs careful scrutiny across these ruptures. Switching from subto supra-state levels, Wilkinson became incorporated in a supra-national institution-making process, carrying with her elements of intellectual continuity from her internationalisms of old, providing an internationalist veneer to new supra-governmental bodies. Of her acquaintances, others such as Negrín and Nehru took different trajectories in relation to the same processes. The implication is clear. Through piecing together individual itineraries and then identifying shared paths, we might understand better the re-making of transnational organizations and ideological internationalism at times of epochal transition.

\author{
TRANSLATED ABSTRACTS \\ FRENCH - GERMAN - SPANISH
}

Matt Perry. À la recherche de "Ellen la rouge" Wilkinson au-delà des frontières et de l'État-nation.

Cet article reconsidère la vie d'Ellen Wilkinson (I89I-I947) - ministre britannique de l'Enseignement de 1945 à 1947 et leader de la Marche de Jarrow de 1936 - en étudiant l'aspect transnational de sa politique. Il tente de montrer l'importance de l'orientation transnationale d'Ellen Wilkinson et comment cette perspective nous permet de compléter et d'approfondir les compréhensions qui existent d'elle. S'inspirant de documents sur des réseaux d'activistes transnationaux, il souligne la complexité de ces réseaux transnationaux et le répertoire de la pratique politique transnationale d'Ellen Wilkinson. Sans une attention accordée à cette dimension mondiale de sa politique, nous avons d'elle une compréhension atténuée et déformée. La conclusion fondamentale est que la construction héroïque d'une "Ellen rouge" dans les textes tant travaillistes que sociaux-féministes a masqué sa seconde radicalisation (1932-1936) et la netteté de sa métamorphose pour en faire une figure officielle du Parti travailliste en 1939-1940.

Traduction: Christine Krätke-Plard

Matt Perry. Auf der Suche nach "Red Ellen” Wilkinson, jenseits der Grenzen und Nationalstaaten.

Dieser Beitrag untersucht aufs Neue das Leben von Ellen Wilkinson (I89I-I947) von 1945 und 1947 britische Erziehungsministerin und 1936 Anführerin der "Jarrow Crusade" - indem er den transnationalen Aspekt ihrer Politik erkundet. Dabei wird versucht, die Bedeutung von Wilkinsons transnationaler Orientierung aufzuzeigen, 
was unser bisheriges Verständnis ihrer Person zu ergänzen und zu vertiefen verspricht. Unter Rückgriff auf die Literatur über transnationale Aktivistennetzwerke skizziert der Beitrag die Komplexität transnationaler Netzwerke und das Repertoire von Wilkinsons transnationaler politischer Praxis. Wird diese globale Dimension ihrer Politik nicht ernsthaft beachtet, dann resultiert ein beschränktes und verkürztes Verständnis von Wilkinsons Person. Ausschlaggebend ist dabei, dass das heroische Konstrukt der "roten Ellen" ("Red Ellen”), wie es sich in den Narrativen sowohl der Labour Party als auch des sozialistischen Feminismus findet, Wilkinsons zweite Radikalisierung (1932-1936) ebenso verdeckt hat wie die Abruptheit ihrer I939/40 erfolgten Verwandlung in eine Labour-Party-Politikerin klassischen Typs.

Übersetzung: Max Henninger

Matt Perry. En busca de "Red Ellen" Wilkinson más allá de las fronteras y dentro del Estado-nación.

En este artículo se ofrece una reconsideración de la vida de Ellen Wilkinson (I89I-1947) - Ministra de Educación británica entre 1957 y 1947 y líder de la Cruzada Jarrow en el año I 936 - en la que se exploran los aspectos transnacionales a través de las políticas que desarrolló. En él buscamos establecer el significado de su orientación transnacional y de qué forma esto nos puede ser útil a la hora de complementar y de profundizar en la comprensión de su vida y existencia. Elaborando un esbozo de la literatura sobre las redes del activismo transnacional, el texto destaca el grado de complejidad de estas redes y el repertorio de la propia Ellen Wilkinson en la práctica política transnacional. Si no prestamos una adecuada atención a esta dimensión global de su política, nuestra comprensión sobre su figura quedaría atenuada, e incluso distorsionada. De forma crucial, la construcción de la imagen heroica de "Red Ellen" (Ellen la Roja), tanto desde la narrativa del laborismo como desde la elaborada por el socialismo feminista, ha contribuido a proyectar zonas sombrías en el proceso de su segunda radicalización (I932-I936) y en su abrupta y rápida metamorfosis en una de las figuras más destacadas del Partido Laborista entre 1939 y 1940.

Traducción: Vicent Sanz Rozalén 